\title{
WHAT MAKES INVESTORS SHORT SELL ETFs?
}

\author{
[Proč investoři shortují ETFs?] \\ Dagmar Linnertová ${ }^{1}$, Oleg Deev ${ }^{2}$ \\ ${ }^{1}$ Masaryk University, Faculty of Economics and Administration, Lipová 41a, 60200 Brno \\ Email: dagmar.linnertova@mail.muni.cz \\ ${ }_{2}^{2}$ Masaryk University, Faculty of Economics and Administration, Lipová 41a, 60200 Brno \\ Email:oleg@mail.muni.cz.
}

\begin{abstract}
Short selling exchange-traded funds (ETFs) has become a common means of speculating or hedging in response to pessimistic expectations about a specific market or sector, as the short interest of ETFs is more than 10 times that of individual stocks, on average. The study determines the specific characteristics of globally available ETFs, which influence the level of short interest (such as trading volume, price stability, market capitalization, expense ratio, geographical focus, investment strategy and the availability of derivatives for the underlying index), and tests three most common short sale motivation hypotheses (overpricing, arbitrage and hedging and transaction costs). Using the monthly short interest ratio and the characteristics of ETFs traded in the US market, empirical evidence to support all three short sale motivation hypotheses is provided. The possibility of achieving abnormal returns based on previous levels of short sale is also tested.
\end{abstract}

Keywords: abnormal returns, exchange-traded funds, short sale.

JEL classification: G10, G14

Doručeno redakci: 27.8.2015; Recenzováno: 28.8.2015; 7.9.2015; 28.9.2015; Schváleno k publikování: 24.8.2016

\section{Introduction}

Exchange traded funds (ETFs) are probably the only example of a successful financial innovation, which not only was not paralyzed during the global financial crisis, but is also getting more prominence in the post-crisis world. The first ETF with a ticker code SPDR was launched in 1993 by American financial-services group State Street and tracked the S\&P500 share index. Twenty years later, there were more than 4500 funds available on the market, allowing investors to invest in almost any asset class focused on any geographical region or industry. Nowadays investors are able to construct a portfolio comprised entirely of ETFs. Such portfolios give a return that is close to the return of the chosen stock market (index) without active portfolio management. The allocation of such a portfolio can be easily changed to markets or industries with higher returns at some particular moment in time. Unsurprisingly, low riskiness, low expenses (compared to active portfolio management) and high liquidity make ETFs greatly attractive to high-frequency traders and hedge funds. Probably the most important, however, not the only one difference of ETFs from open-end mutual funds is that they are traded continuously in an exchange, thus, they are necessarily traded at their net asset value. Without any doubt, the growth of the ETF market will continue in the nearest future.

Popularity of ETFs can also be explained by the possibility of the short selling of such funds, which provides market participants with the means to speculate or hedge based on pessimistic expectations about a specific market or sector. ETFs can be shorted or bought on margin exactly as any individual stock; moreover, ETFs are not subject to short sale ban or other short selling regulations. Although short sellers play an important role in ensuring efficiency in markets, there is little known about the determinants of short sellers' activities, which are 
significantly increasing both in volume and in number of transactions. The goal of this paper is to provide an empirical assessment of such determinants. In other words, we are aimed to establish why some ETFs are more attractive for investors to sale short than others and how a short selling activity influences the subsequent performance of exchange-traded funds. Additionally, we are aiming to establish if short sellers are smart investors able to achieve abnormal returns. Generally, ETFs are expected to have price behavior similar to usual stocks. However, the empirical research on the short selling of stocks is based on firm-specific determinants, such as firms' earnings announcements and fundamentals-to-price ratios. ETFs as portfolios cannot be monitored by market participants in the same manner, and hence, should be additionally investigated.

Theoretically, short selling is considered to be a costly and risky transaction applied only with strong belief that security price will decline (Diamond and Verrecchia 1987). Recent empirical studies on short selling with stocks (such as Diether et al. 2009) find a link between high short interest and subsequent negative abnormal returns. Moreover, short sellers increase trading following prolonged positive returns, thus actively exploiting overpriced stocks. Since exchange traded funds represent market portfolios and not individual companies, it is certainly more difficult to follow and predict the development of different geographical or sectoral stock markets, thus, providing more opportunities for hedging and arbitrage (the rationale for short selling with ETFs is discussed in detail in the following section). This paper contributes to the literature in the following way. First, it summarizes the theoretical rationale for short selling with exchange-traded funds formulated in three hypotheses. Second, it provides empirical evidence on the formulated hypotheses and shows that short sale does not lead to better ETF portfolio performance (in other words, short selling with ETFs does not lead to abnormal returns).

\section{Rationale for short selling with ETFs}

According to Kot (2007), the motivation behind short selling of stocks can be summarized in four main hypotheses, which we also consider as the rationale for short selling with ETFs. The trend hypothesis, which basically explains the nature of short selling, suggests that some investors are trend-traders by selling or short selling securities, if their short term past prices are decreasing. If the stock prices are increasing in the short run period, short sellers close their positions. The overpricing hypothesis (also known as Miller's hypothesis, Miller (1977)) states that short sellers trade in the situation when there is a poor future perspective for the security. Therefore, short sale is a method to push security prices back to their fundamental values. The securities in a market with the restricted short sale or short sale constraints have a tendency to be overpriced because there is an absence of mechanism that returns security prices to their fundamental values. The short sellers trade only if the expected decrease in security prices is enough to compensate all costs and risks of short selling (Diamond and Verrechia, 1987). Thus, the overpricing hypothesis also emphasizes the importance of transaction costs. The arbitrage and hedging hypothesis offers investors an arbitrage profit because of the difference between the underlying security and the convertible or derivative security (Dechow et al., 2001). The tax hypothesis is based on tax benefits when investors short sell the security while holding a long position in the same security, but do not deliver the security to cover the short position. This action is called short sale against the box. Changes in tax regulations in different countries (e.g. Taxpayer Relief Act in 1997 in the United States) have eliminated this opportunity for tax optimization; hence, it is not a motivation for short selling anymore. 
The majority of studies on determinants of short selling are focused on stocks rather than other financial instruments. Here we summarize only most relevant results. Brent et al. (1990) investigate the short interest ratio determinants corresponding to three hypotheses: trend, arbitrage and tax hypotheses. Using cross sectional and time series tests they show that individual stocks with high betas and tradable option have a higher level of short interest that is consistent with the arbitrage strategy. Dechow et al. (2001) address the issues of transaction costs. They focus on the analysis of stock fundamentals and their impact onto the short interest ratio and suggest that stocks with low ratios of fundamentals to market values are more attractive to short sellers. Angel et al. (2003) examine short sales on NASDAQ and suggest that short sellers target the most volatile and most actively traded stocks. They find out that short selling is more common for high returns and actively traded stocks and that short selling varies with shares price volatility. Kot (2007) considers several factors to explain the rationale behind short sale in NYSE and NASDAQ in the period 1988 - 2002. This paper represents the most complete view of determinants influencing the short interest level by demonstrating that short-selling activity is positively related to arbitrage opportunities and hedging demand. McKenzie and Henry (2006) analyze short selling determinants on an intraday basis in the Hong Kong stock market. Their study reveals that intraday short interest levels are determined by the dividend payments, company fundamentals, risk, option trading, the interest rate spreads and past returns.

To our knowledge, there is only one study investigating short selling with ETFs. Madura and Ngo (2008) analyze the ETFs short sale determinants in AMEX in years 2001- 2004 using the cross sectional analysis and Fama-MacBeth regression. They discover that short interest is large for sector ETFs and small for international ETFs, for ETFs that have a higher trading volume and for ETFs with low market capitalization and low expense ratio. In this study, short interest is also low for ETFs representing a particular index or having other tradable derivative. However, there are several shortcomings to their findings. First, the dataset contains ETFs listed on the American Stock Exchange (AMEX) only. The popularity of ETFs on European and Asian stock exchanges might be explained by other factors, where the types of ETFs are usually classified differently. Second, the data sample does not include the periods of the global financial crisis and the period after it, when the general popularity of ETFs grew significantly. Third, due to the construction of the dataset several important ETF characteristics were left out, such as geographical focus, tracking error and replication strategy.

Previous studies set the group of determinants that could affect the level of the short interest ratio. These determinants, their expected impact on the short interest ratio (SIR) and corresponding motivation hypothesis are summarized in Table 1. 
Table 1: Possible motivation for short selling with ETFs

\begin{tabular}{|l|l|l|}
\hline \multicolumn{1}{|c|}{ Variable } & \multicolumn{1}{|c|}{$\begin{array}{c}\text { Expected impact } \\
\text { on short interest ratio }\end{array}$} & \multicolumn{1}{c|}{ Motivation } \\
\hline Rate of return & Positive & Overpricing hypothesis \\
\hline Number of ETFs shares outstanding & $\begin{array}{l}\text { Positive } \\
\text { Negative }\end{array}$ & $\begin{array}{l}\text { Transaction costs } \\
\text { Overpricing hypothesis }\end{array}$ \\
\hline Trading volume & $\begin{array}{l}\text { Positive } \\
\text { Negative }\end{array}$ & $\begin{array}{l}\text { Transaction costs } \\
\text { Overpricing hypothesis }\end{array}$ \\
\hline Volatility & Positive & Overpricing hypothesis \\
\hline Market capitalization & Positive & Transaction costs \\
\hline Raw Beta & Positive & Arbitrage and hedging hypothesis \\
\hline $\begin{array}{c}\text { Replication strategy of ETFs: } \\
-\quad \text { Full replication }\end{array}$ & - Positive \\
$-\quad$ Synthetic replication & - Negative & Arbitrage and hedging hypothesis \\
\hline $\begin{array}{c}\text { Focus of ETFs base on market capitalization: } \\
-\quad \text { Small / middle }\end{array}$ & - Positive & - Negative \\
\hline Fund expense ratio & Negative & Overpricing hypothesis \\
\hline Option available & Negative & Transaction costs \\
\hline Type of ETFs (sectoral, geographical) & Positive & Transaction costs \\
\hline
\end{tabular}

Source: authors' compilation

Short selling might be also applied to achieve higher returns on group of assets. Historically, two approaches aim to clarify the relationship between short sale and subsequent market performance. The older attitude considers a short sale level as a bearish signal. Since, short sellers open their short positions only if they have relevant negative information and they are sure about the future market decreasing. The current approach is represented by the technical analyst's insight that takes a short position as a bullish signal through potential demand that it represents. According to their opinion, all open short positions must be closed out in the future hence shorted securities will be demanded and their prices will be pushed up. By studying both determinants of short selling and subsequent performance for exchange-traded funds, we can evaluate the impact of short selling with ETFs on the market.

Biggs (1966), Seneca (1967), Smith (1968), Mayor (1968) and Kerrigan (1974). Biggs (1966) are the initial studies investigating the impact of short sale level on further securities performance. Biggs (1966) analyses the so called "legend" about increasing the short sale level as a bullish indicator and decreasing level as a bearish signal. His investigation is based on the technical analysis term called a contrary opinion. Securities with the increasing short sale level offer growing potential but according to his opinion it is mostly in consequence of changes in the fundamental characteristics of a company or changes in the economy than due to the previous level of short sale. Seneca (1967) analyses both prevailing approaches to the short sale level as an indicator of subsequent market performance. His analysis is based on the US market data between 1966 and 1967 and supports the idea about the bearish signal of the short sale level. Smith (1968) assumes that the growing short sale level indicates subsequent bullish market, however, the results do not support this expectation but find out that securities with a higher short sale level are more volatile.

Other studies analyze not only returns but also risk factor in short selling. McDonald and Baron (1973) reject both the technical analysts approach as well as the short sale level as a bearish indicator. Other authors analyze the impact of the legislative short sale regulation on market see Figlewski (1981) or Boehmer at al. (2008). The idea of the relationship between short sale levels and subsequent performance is reconsidered in the literature in the late 1990s. 
Figure 1: Short interest ratios for American ETFs and S\&P500 index

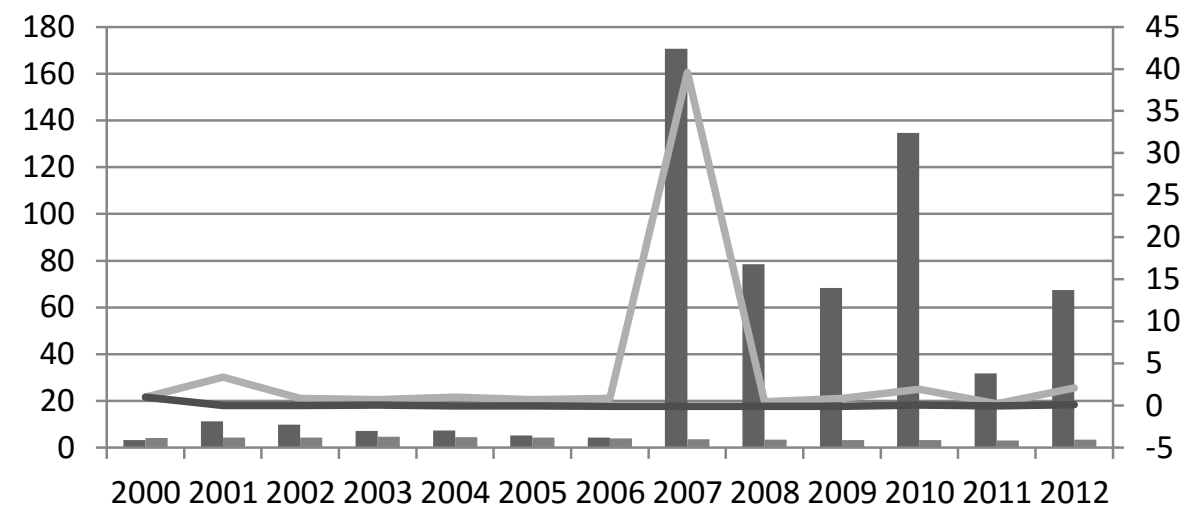

$\begin{array}{ll}\text { SIR ETFs (monthly) } & \text { SIR S\&P } 500 \text { (monthly) } \\ \text { change of SIR ETFs (in \%) } \quad \text { change of SIR S\&P } 500 \text { (in \%) }\end{array}$

Note: left scale indicates days, right scale indicates percentages

Source: authors' calculations based on data from Bloomberg

Table 2: Variable definitions

\begin{tabular}{|c|c|c|}
\hline Name & Variable & Definition \\
\hline$S I R_{i t}$ & Short interest ratio & $\begin{array}{l}\text { The total number of shares an investor has sold short divided by the average } \\
\text { monthly trading volume for a specific period }\end{array}$ \\
\hline LAG.RATE ${ }_{i t}$ & $\begin{array}{l}\text { Rate of return } 3,6,9 \text { and } \\
12 \text {-month lag }\end{array}$ & Performance of ETF measured as a lagged return on ETF \\
\hline SHARES $_{\text {it }}$ & $\begin{array}{l}\text { Number of ETFs shares } \\
\text { outstanding }\end{array}$ & Total number of shares outstanding of each ETF in the end of each month \\
\hline VOLUME & Trading volume & Logarithmic mean trading volume of the ETF per month \\
\hline VOLATILITY $_{i t}$ & Volatility of the ETF & $\begin{array}{l}\text { The } 90 \text {-day price volatility equals the annualized standard deviation of the } \\
\text { relative price change for the } 90 \text { most recent trading days closing price, } \\
\text { expressed as a percentage }\end{array}$ \\
\hline MARKETCAP ${ }_{i t}$ & Market capitalization & Logarithmic market capitalization of the ETF per month \\
\hline$B E T A_{i t}$ & Raw Beta & $\begin{array}{l}\text { Volatility measure of the percentage price change of the security given a one } \\
\text { percent change in a representative market index }\end{array}$ \\
\hline REPLICATION $_{i}$ & $\begin{array}{l}\text { Dummy for replication } \\
\text { strategy }\end{array}$ & $\begin{array}{l}\text { Replication strategy of ETFs: } \\
\text { Full replication, synthetic replication or otherwise optimized }\end{array}$ \\
\hline FOCUS.CAP $_{i}$ & $\begin{array}{l}\text { Dummy for the ETF's } \\
\text { market capitalization } \\
\text { focus }\end{array}$ & $\begin{array}{l}\text { The focus the fund intends to keep according to market capitalization: } \\
\text { Large cap with capitalization over } 8 \text { billion USD } \\
\text { Midcap with capitalization between } 1,5 \text { billion to } 8 \text { billion } \\
\text { Small cap with capitalization less } 1,5 \text { billion USD } \\
\text { Multi cap }\end{array}$ \\
\hline EXPENSE $_{i t}$ & Fund expense ratio & The amount investors paid for expenses incurred in operating a fund \\
\hline OPTIONS $_{i}$ & $\begin{array}{l}\text { Dummy for the } \\
\text { availability of derivative }\end{array}$ & $\begin{array}{l}\text { Indicates whether options are available on the same security or not (1 if options } \\
\text { are available on the security, } 0 \text { otherwise) }\end{array}$ \\
\hline $\begin{array}{l}\text { SECTOR }_{i} \\
\text { GEO }_{i} \\
\text { EMERGING }_{i}\end{array}$ & $\begin{array}{l}\text { Dummies for the ETF's } \\
\text { market segment or sector } \\
\text { focus }\end{array}$ & $\begin{array}{l}\text { The focus the fund intends to keep based on market segment or sector: } \\
\text { Sector ETFs (SECTOR } \text { S }_{i}-1 \text { if Technology Sector, } 2 \text { if Financial Services, } 3 \text { if } \\
\text { Energy Sector, } 4 \text { if Precious Metals, } 0 \text { otherwise) } \\
\text { Geographically focused ETFs }\left(\mathrm{GEO}_{i}-1 \text { if Global, } 2 \text { if International, } 3 \text { if North }\right. \\
\text { America, } 4 \text { if European Region, } 5 \text { if Asian, } 0 \text { otherwise) } \\
\text { Emerging markets ETFs (EMERGING }{ }_{i} \text { ) }\end{array}$ \\
\hline
\end{tabular}

Source: authors' compilation

Aitkem et al. (1998) analyze the impact of the short sale level on subsequent security prices on an intraday basis in the Australian capital market. The average level of decline was $-0,20$ percent for the securities with the highest level of short sale within 15 minutes. Desai et al. (2002) investigate the information role of the short sale level in NASDAQ between 1988 1994. They find out the statistically significant negative abnormal return between $-0,76$ to 1,13 percent per month for the securities with the highest short sale level. But according to their findings, the reaction is gradual and thus they confirm the application of the short sale 
level as the bearish signal. Angel et al. (2003) support results of Desai et al. (2002). Acker et al. (2005) analyze the Canadian market and find out a negative correlation between short sale and subsequent excess return of securities. They point out that short sale as a bearish signal is more quality indicator in the Canadian market than in the U.S. market because of the lack of regulations and bans of this market activity in Canada. Boehmer et al. (2008) analyze monthly short sale between 1988 and 2005 in NYSE, Amex and NASDAQ. Their results support the idea about the negative abnormal returns of securities with the highest short sale level and about statistically significant positive abnormal returns of securities with the lowest short sale level.

\section{Methodology and data}

For the purposes of our study, we considered all exchange-traded funds listed on three American exchanges: NYSE Arca, NASDAQ and BATS from January 2000 to December 2012. All ETFs are actively traded on Bloomberg. The obtained dataset of 1324 ETFs is based on 206388 monthly observations. We divided our dataset into three sub-periods to reflect different economical and financial conditions. The period of $2000-2006$ is a time of economic growth. The first years of 2000s were weak because of uncertainty following the September 2001 crisis and fraud cases of corporations, although the US economy improved during 2003 and was generally stable till the end of this sub-period. The $2007-2008$ subperiod represents the financial market uncertainty, the real estate bubble and the sub-prime mortgage crisis transitioned into the global financial crisis. The last period $2009-2012$ represents few first years of slight global economic recovery.

The preliminary statistical analysis of short interest levels displays growing importance of short selling of ETFs as everyday tool of fund managers and other traders. Short selling activities with ETFs grew significantly after the crisis and are staying in elevated levels. At the same time, mean of short interest ratio is declining due to the growth of the number of ETFs available on the markets.

We furthermore obtain price information and general characteristics of the chosen exchangetraded funds, which should be easily available to investors or any other market participant. The full description of variables selected for the analysis is provided in Table 2 .

The identification of determinants of the ETFs short selling activity is based on the following multivariate model for a panel of data comprising all determinants from Table 2. Two general methods for estimations of panel data models without cross-sectional bias are applied: fixed effects and least squares dummy variables (LSDV). Model residuals were tested for homoscedasticity using Breusch-Pagan test. Multicollinearity is detected by calculating variance inflation factors (VIF).

As the second part of our analysis, we examine the relationship between short interest and subsequent performance of the ETFs or, in other words, we test whether the trading strategies based on the previous short interest level result in abnormal returns. The abnormal return or excess return is represented by a performance of a security against a particular benchmark. The abnormal return is positive, if the rate of return is higher than the benchmark, or negative, if the abnormal return is lower than the benchmark. We assume that the portfolio of ETFs based on the highest short sale level will produce statistically significant lower abnormal returns than the portfolio of ETFs with the higher short sale level.

The applied methodology is based on the analysis of Jagadeesh and Titman (1993) that examines the reaction of security prices to particular information and market tendency to over or undervalue such information. A similar strategy can be found in studies of Baytas and 
Cakici (1999) or Madura and Ngo (2008). The mentioned strategy contains two steps. First, portfolios based on the previous short sale level are created, where the short sale level is measured by the so called short sale interest. This variable informs about the absolute number of the particular security shares that are sold short in a particular month and the position has not been closed until the end of month. The first portfolio contains ETFs with the highest level of short sale; the last portfolio contains ETFs with the lowest value of short sale in the referential period. For the referential period, the short interests in December and July were considered. The portfolios are re-arranged according to the level of short sale in these periods. The second step represents the evaluation of how a particular portfolio performs in next 1,3 and 6 month periods. The performance of portfolios is measured by abnormal returns. The statistical significance of these abnormal returns is examined by t-tests and the difference of abnormal returns between portfolio with the highest and lowest short sale level is tested by the pair t-test.

Table 3: Description statistics

\begin{tabular}{|c|c|c|c|c|}
\hline Variable & Full sample & $2000-2006$ & $2007-2009$ & $2010-2012$ \\
\hline $\begin{array}{l}S_{\text {SIt }} \\
\text { Mean } \\
\text { Median } \\
\text { Standard deviation } \\
\end{array}$ & $\begin{array}{l}3.05 \\
1.02 \\
0.101 \\
\end{array}$ & $\begin{array}{l}6.5 \\
3.43 \\
0.114 \\
\end{array}$ & $\begin{array}{l}92.347 \\
0.810 \\
8.62 \\
\end{array}$ & $\begin{array}{l}2.578 \\
0.930 \\
1.017 \\
\end{array}$ \\
\hline $\begin{array}{l}\text { SHARES }_{i t} \\
\text { Mean } \\
\text { Median } \\
\text { Standard deviation }\end{array}$ & $\begin{array}{l}20.8 \\
2.85 \\
71.5\end{array}$ & $\begin{array}{l}25.41 \\
4.45 \\
81.1\end{array}$ & $\begin{array}{l}20.17 \\
2.75 \\
672\end{array}$ & $\begin{array}{l}19.748 \\
2.40 \\
70.73\end{array}$ \\
\hline $\begin{array}{l}\text { VOLATILITY }_{i t} \\
\text { Mean } \\
\text { Median } \\
\text { Standard deviation }\end{array}$ & $\begin{array}{l}27.00 \\
21.66 \\
20.4\end{array}$ & $\begin{array}{l}19.22 \\
16.49 \\
9.96\end{array}$ & $\begin{array}{l}35.398 \\
27.258 \\
26.2\end{array}$ & $\begin{array}{l}23.019 \\
20.327 \\
15.4\end{array}$ \\
\hline $\begin{array}{l}\text { MARKETCAP } P_{i t} \\
\text { Mean } \\
\text { Median } \\
\text { Standard deviation } \\
\end{array}$ & $\begin{array}{l}1.75 \\
1.76 \\
0.67 \\
\end{array}$ & $\begin{array}{l}1.88 \\
1.85 \\
0.61 \\
\end{array}$ & $\begin{array}{l}1.69 \\
1.71 \\
0.68 \\
\end{array}$ & $\begin{array}{l}1.63 \\
1.61 \\
0.72 \\
\end{array}$ \\
\hline $\begin{array}{l}B E T A_{i t} \\
\text { Mean } \\
\text { Median } \\
\text { Standard deviation }\end{array}$ & $\begin{array}{l}0.91 \\
1.02 \\
0.701 \\
\end{array}$ & $\begin{array}{l}1.07 \\
1.02 \\
0.51 \\
\end{array}$ & $\begin{array}{l}0.908 \\
1.023 \\
0.685 \\
\end{array}$ & $\begin{array}{l}0.876 \\
1.024 \\
0.751 \\
\end{array}$ \\
\hline $\begin{array}{l}V O L U M E_{i t} \\
\text { Mean } \\
\text { Median } \\
\text { Standard deviation }\end{array}$ & $\begin{array}{l}6.17 \\
6.08 \\
0.99\end{array}$ & $\begin{array}{l}5.66 \\
5.65 \\
0.68\end{array}$ & $\begin{array}{l}5.98 \\
5.57 \\
0.93\end{array}$ & $\begin{array}{l}6.01 \\
5.89 \\
0.99\end{array}$ \\
\hline $\begin{array}{l}\text { LAG.RATE. } 3_{i t} \\
\text { Mean } \\
\text { Median } \\
\text { Standard deviation }\end{array}$ & $\begin{array}{l}0.00 \\
0.00 \\
0.0793 \\
\end{array}$ & $\begin{array}{l}0.01 \\
0.01 \\
0.0541 \\
\end{array}$ & $\begin{array}{l}-0.05 \\
0.01 \\
0.0949 \\
\end{array}$ & $\begin{array}{l}0.006 \\
0.008 \\
0.0707 \\
\end{array}$ \\
\hline $\begin{array}{l}\text { LAG.RATE. } \sigma_{i t} \\
\text { Mean } \\
\text { Median } \\
\text { Standard deviation }\end{array}$ & $\begin{array}{l}0.00 \\
0.00 \\
0.0808 \\
\end{array}$ & $\begin{array}{l}0.01 \\
0.01 \\
0.0556\end{array}$ & $\begin{array}{l}-0.002 \\
-0.012 \\
0.0959\end{array}$ & $\begin{array}{l}0.000 \\
0.003 \\
0.0841\end{array}$ \\
\hline $\begin{array}{l}\text { LAG.RATE. } 9_{i t} \\
\text { Mean } \\
\text { Median } \\
\text { Standard deviation }\end{array}$ & $\begin{array}{l}0.00 \\
0.00 \\
0.0811 \\
\end{array}$ & $\begin{array}{l}0.01 \\
0.01 \\
0.0566\end{array}$ & $\begin{array}{l}-0.006 \\
-0.002 \\
0.0927\end{array}$ & $\begin{array}{l}0.006 \\
0.004 \\
0.0819 \\
\end{array}$ \\
\hline $\begin{array}{l}\text { LAG.RATE. } 12_{i t} \\
\text { Mean } \\
\text { Median } \\
\text { Standard deviation }\end{array}$ & $\begin{array}{l}0.00 \\
0.00 \\
0.0816\end{array}$ & $\begin{array}{l}0.01 \\
0.01 \\
0.0578\end{array}$ & $\begin{array}{l}-0.01 \\
0.00 \\
0.0806\end{array}$ & $\begin{array}{l}0.003 \\
0.002 \\
0.0902\end{array}$ \\
\hline
\end{tabular}

Source: authors' compilation

The calculation of the abnormal return is based on monthly observations and the following formula: 


$$
A R R_{i}=\sum_{k=1}^{N} \frac{A R R_{i k}}{N}=\frac{\sum_{k=1}^{N}\left(R R_{i k}-I R R_{i k}\right)}{N}
$$

where $A R R_{i}$ is an abnormal return of the portfolio, $i$ is the period (in months) for which the performance is calculated $(i=1,3,6) . A R R_{i}$ represents the difference between $R R_{i k}$, rate of return of a particular portfolio and $I R R_{i k}$, a specific market benchmark. As a benchmark of the US market the S\&P 500 index was used.

\section{Results and discussion}

Results of the multivariate analysis of short interest determinants are reported in Table 4. The following factors have a negative affect on the SIR level: the number of shares outstanding, the volatility and expense ratio of ETFs. The positive effect on short selling activities is found for a beta coefficient, a replication strategy based on a full replication and focus of ETFs on sector stocks. On the other hand, the previous performance of ETFs does not influence short sellers' decisions. However, the significance of the ETFs characteristics on short sale activities are mixed (e.g. market capitalization or option alternative are significant but only in the particular period).

Table 4: Estimation results

\begin{tabular}{|c|c|c|c|c|c|c|c|c|}
\hline \multirow{2}{*}{ Variable } & \multicolumn{2}{|c|}{ Full sample } & \multicolumn{2}{|c|}{$2000-2006$} & \multicolumn{2}{|c|}{$2007-2009$} & \multicolumn{2}{|c|}{$2010-2012$} \\
\hline & FE & LSDV & FE & LSDV & FE & LSDV & FE & LSDV \\
\hline Intercept & $6.606 * * *$ & - & $9.586 * * *$ & - & $9.901 * * *$ & - & $9.585 * * *$ & - \\
\hline$S_{\text {SHARES }}$ & $-0.001 * * *$ & $-0.004 * * *$ & $-0.229 * * *$ & -0.038 & $-0.005 * *$ & $-0.029 * *$ & $-0.001 * * *$ & $-0.028 * * *$ \\
\hline VOLATILITY $_{i t}$ & $-0.021 * * *$ & $-0.011 * * *$ & $0.012 * * *$ & $-0.164 * * *$ & $-0.016 * * *$ & $-0.020 * * *$ & $-0.014 * * *$ & $-0.011 * * *$ \\
\hline MARKETCAP $_{i t}$ & -1.696 & -1.059 & $-0.631 * *$ & $-0.598 * * *$ & 1.513 & 1.069 & -0.403 & -0.309 \\
\hline$B E T A_{i t}$ & $0.208 * * *$ & $0.198 * * *$ & -0.284 & $0.293 * * *$ & $0.552 * * *$ & $0.320 * *$ & $0.105^{* * *}$ & $0.129 * *$ \\
\hline$V O L U M E_{i t}$ & -0.021 & 0.011 & 0.012 & $0.009 *$ & -0.016 & -0.008 & 0.001 & 0.059 \\
\hline$L A G .3_{i t}$ & $-1.084 * * *$ & $-0.733^{*}$ & -5.742 & 0.306 & -0.168 & -0.389 & -0.012 & -0.243 \\
\hline LAG. $6_{i t}$ & $-0.388^{*}$ & -0.419 & -2.913 & 1.708 & -0.133 & -0.812 & -0.436 & -0.368 \\
\hline$L A G .9_{i t}$ & 0.038 & 0.259 & $-3.248 * *$ & -2.340 & $2.005 * * *$ & $1.753 * *$ & -0.309 & -0.202 \\
\hline$L A G .12_{i t}$ & 0.597 & -0.115 & 1.887 & 1.293 & $2.840 * * *$ & 0.009 & -0.278 & -0.286 \\
\hline REPLI.SYN & 0.024 & -0.183 & - & - & -0.003 & 0.068 & $0.268 *$ & 0.236 \\
\hline REPLI.FULL $L_{i}$ & $0.399 * * *$ & $0.378 * * *$ & -0.256 & -0.376 & $0.799 * * *$ & $0.723 * * *$ & $0.398 * * *$ & $0.390 * * *$ \\
\hline FOCUS.LCAP ${ }_{i}$ & $0.523 * * *$ & $0.401 * * *$ & $1.705 * * *$ & $1.323 * *$ & -0.198 & $-0.385^{*}$ & -0.009 & -0.100 \\
\hline FOCUS.SCAP & $0.032 * * *$ & -0.054 & $-1.023^{*}$ & $-1.709 * *$ & -0.099 & -0.114 & $0.398^{* * *}$ & $0.294 * * *$ \\
\hline FOCUS.MCAP & $0.232 * * *$ & 0.169 & $1.996 * * *$ & $1.406 *$ & -0.803 & $-0.701 * *$ & 0.001 & 0.070 \\
\hline FOCUS.MULTICAP $_{i}$ & $0.524 * * *$ & $0.508 * * *$ & $0.782 * *$ & 0.529 & 0.303 & 0.334 & $0.458^{*}$ & $0.501 * *$ \\
\hline EXPENSE $_{i t}$ & $-0.823 * * *$ & $-0.728 * * *$ & $-5.057 * * *$ & $-5.281 * * *$ & -0.296 & -0.250 & $-0.429 * *$ & $-0.425 * *$ \\
\hline OPTIONS $_{i}$ & $0.235^{* * *}$ & -0.109 & 0.325 & -0.479 & $-0.578 * * *$ & $-0.559 * * *$ & $0.230 * * *$ & $0.214 * * *$ \\
\hline$S_{E C T O R}$ & $1.365 * * *$ & $1.259 * * *$ & $0.997 * *$ & $1.130 * *$ & $1.908 * * *$ & $1.263 * * *$ & $1.339 * * *$ & $1.327 * * *$ \\
\hline$G E O_{i}$ & 0.002 & -0.005 & -0.326 & -0.292 & -0.034 & 0.055 & $0.398 * * *$ & $0.400 * * *$ \\
\hline EMERGING $_{i}$ & 0.243 & 0.300 & -0.201 & -0.186 & -0.006 & 0.086 & $0.409 * *$ & $0.400^{*}$ \\
\hline$R^{2}$ & $0.283 * * *$ & $0.201 * * *$ & $0.291 * * *$ & $0.359 * * *$ & $0.404 * * *$ & $0.139 * * *$ & $0.265 * * *$ & $0.197 * * *$ \\
\hline
\end{tabular}

Note: *, **, *** indicates significance at the 90\%, 95\%, and 99\% level, respectively

Source: authors' calculations

The most negative powerful factor is the expense ratio. The increase of this variable per unit (1 p.p.) leads to the 0.72 days average decrease of the SIR, if other factors are held constant. In the pre-crisis period, it contributes to the 0.52 days decrease of the SIR level, however, this affect disappears during the financial crisis, but resurfaces after the crisis at 0.43 days decline 
ceteris paribus. This finding confirms the expectation about the negative influence of transaction costs on short selling.

The volatility is negative and statistically significant in all analyzed periods. The strongest influence of this factor on the short interest ratio is apparent in the pre-crisis period, when the 1 p.p. increase of volatility leads to 0.15 days decline of the SIR ceteris paribus. In other periods, this effect was lower -0.12 days on average. This finding contradicts expectations of positive effect of volatility on short selling activities due to higher probability of overpricing. Hence, the volatility more likely reflects the uncertainty, rather than overpricing tendencies.

Table 5: An example of returns for ETF portfolios based on short sale activity

\begin{tabular}{|c|c|c|c|c|}
\hline \multicolumn{2}{|c|}{ Period/Portfolio } & $\begin{array}{l}\text { Portfolio } 1 \\
\text { (High SIR) }\end{array}$ & $\begin{array}{c}\text { Portfolio } 10 \\
\text { (Low SIR) }\end{array}$ & $\begin{array}{l}\text { Difference in } \\
\text { returns between } \\
\text { portfolios } 1 \text { and } 10\end{array}$ \\
\hline \multirow{3}{*}{$2001 / 1^{\mathrm{st}}$} & $1 \mathrm{M}$ & - & - & - \\
\hline & $3 \mathrm{M}$ & $0,038 * *$ & 0,043 & $-0,005 * *$ \\
\hline & $6 \mathrm{M}$ & 0,030 & 0,021 & 0,009 \\
\hline \multirow{3}{*}{$2001 / 2^{\text {nd }}$} & $1 \mathrm{M}$ & 0,029 & 0,011 & $0,018 * *$ \\
\hline & $3 \mathrm{M}$ & $0,035 * *$ & $-0,009$ & 0,044 \\
\hline & $6 \mathrm{M}$ & $-0,010$ & $-0,003$ & $-0,007 * *$ \\
\hline \multirow{3}{*}{$2002 / 1^{\text {st }}$} & $1 \mathrm{M}$ & 0,010 & 0,103 & $-0,003$ \\
\hline & $3 \mathrm{M}$ & $-0,038 * *$ & $-0,024$ & $-0,014$ \\
\hline & $6 \mathrm{M}$ & $-0,004$ & $-0,004$ & 0,000 \\
\hline \multirow{3}{*}{$2002 / 2^{\text {nd }}$} & $1 \mathrm{M}$ & $-0,023$ & 0,001 & $-0,022$ \\
\hline & $3 \mathrm{M}$ & $-0,052 * * *$ & $-0,051 * * *$ & $-0,001$ \\
\hline & $6 \mathrm{M}$ & $-0,004$ & 0,001 & $-0,005$ \\
\hline \multirow{3}{*}{$2003 / 1^{\text {st }}$} & $1 \mathrm{M}$ & 0,007 & 0,002 & 0,005 \\
\hline & $3 \mathrm{M}$ & $0,056 * *$ & $0,071 * * *$ & $-0,015$ \\
\hline & $6 \mathrm{M}$ & $-0,112 * * *$ & $-0,112 * *$ & 0,000 \\
\hline \multirow{3}{*}{$2003 / 2^{\text {nd }}$} & $1 \mathrm{M}$ & $-0,103 * * *$ & $-0,092 * * *$ & $-0,011$ \\
\hline & $3 \mathrm{M}$ & $-0,202 * * *$ & $-0,170 * * *$ & $-0,032$ \\
\hline & $6 \mathrm{M}$ & $-0,235 * * *$ & $-0,222 * * *$ & $-0,013$ \\
\hline \multirow{3}{*}{$2004 / 1^{\mathrm{st}}$} & $1 \mathrm{M}$ & $-0,047 * * *$ & $-0,021$ & $-0,026$ \\
\hline & $3 \mathrm{M}$ & $-0,049 * * *$ & $-0,048 * *$ & $-0,001$ \\
\hline & $6 \mathrm{M}$ & $0,103 * * *$ & $0,084 * *$ & 0,019 \\
\hline \multirow{3}{*}{$2004 / 2^{\text {nd }}$} & $1 \mathrm{M}$ & $0,063 * * *$ & $0,075^{* * *}$ & $-0,012 * *$ \\
\hline & $3 \mathrm{M}$ & $0,063 * * *$ & $0,047 * * *$ & 0,016 \\
\hline & $6 \mathrm{M}$ & $0,074 * *$ & 0,030 & $-0,044$ \\
\hline \multirow{3}{*}{$2005 / 1^{\text {st }}$} & $1 \mathrm{M}$ & $0,041 * * *$ & $0,048 * * *$ & $-0,007$ \\
\hline & $3 \mathrm{M}$ & $0,051 * * *$ & $0,030 * * *$ & 0,021 \\
\hline & $6 \mathrm{M}$ & $0,044 * * *$ & $0,017 *$ & 0,027 \\
\hline \multirow{3}{*}{$2005 / 2^{\text {nd }}$} & $1 \mathrm{M}$ & $-0,082 * * *$ & $-0,064 * * *$ & $-0,018$ \\
\hline & $3 \mathrm{M}$ & $-0,050 * * *$ & $-0,024 * *$ & $-0,026^{*}$ \\
\hline & $6 \mathrm{M}$ & $0,052 * * *$ & 0,045 & 0,007 \\
\hline \multirow{3}{*}{$2006 / 1^{\text {st }}$} & $1 \mathrm{M}$ & $-0,065 * * *$ & $-0,051 * * *$ & $-0,014 * * *$ \\
\hline & $3 \mathrm{M}$ & $-0,082 * * *$ & $-0,040 * * *$ & $-0,042 * *$ \\
\hline & $6 \mathrm{M}$ & $-0,047 * * *$ & $-0,018^{*}$ & $-0,029 *$ \\
\hline \multirow{3}{*}{$2006 / 2^{\text {nd }}$} & $1 \mathrm{M}$ & $0,039 * * *$ & $0,043 * *$ & $-0,004 * * *$ \\
\hline & $3 \mathrm{M}$ & $-0,027 * * *$ & $-0,019 * *$ & $-0,006$ \\
\hline & $6 \mathrm{M}$ & $-0,080 * * *$ & $0,061 * * *$ & $-0,019$ \\
\hline
\end{tabular}

Note: *, **, *** indicates significance at the 90\%, 95\%, and 99\% level, respectively Source: authors' calculations

The amount of shares outstanding only slightly reduces the SIR level ( 0.0044 days per unit on average). This finding corresponds with the transaction costs hypothesis rather than the overpricing hypothesis. 
The increasing beta coefficient leads to the average 0.20 days increase of the SIR. This variable is the most significant in the pre-crisis period, when it increases the level of the SIR for about 3 days. In other periods, this effect is weaker. This finding is consistent with the arbitrage and hedging hypothesis.

The initial characteristics of exchange-traded funds have generally positive effects on short selling activities. The full replication strategy results in on average 0.39 days higher short interest ratio. However, the synthetic replication does not seem to have an effect on short interest. Evidently, the full replication is a major trading indicator of ETFs for traders with more significant role in crisis. Such precarious tracking of the underlying asset is indicative of the arbitrage and hedging hypothesis. The sectoral and geographical characteristics of ETFs also results in significantly higher short interest ratio (1.3 days on average). This finding supports the overpricing hypothesis.

We created 240 portfolios for the second part of our analysis. Table 5 provides a shortened example of our calculations - here we show returns for only two portfolios based on the size of the short positions in the pre-crisis period and the difference between them.

Table 6: Aggregated average abnormal returns of tested portfolios

\begin{tabular}{|l|c|c|c|c|c|c|c|c|c|c|c|c|}
\hline Period & \multicolumn{3}{|c|}{$2000-2012$} & \multicolumn{3}{c|}{$2000-2006$} & \multicolumn{3}{c|}{$2007-2009$} & \multicolumn{3}{c|}{$2010-2012$} \\
\hline \multirow{2}{*}{ Return } & $1 \mathrm{M}$ & $3 \mathrm{M}$ & $6 \mathrm{M}$ & $1 \mathrm{M}$ & $3 \mathrm{M}$ & $6 \mathrm{M}$ & $1 \mathrm{M}$ & $3 \mathrm{M}$ & $6 \mathrm{M}$ & $1 \mathrm{M}$ & $3 \mathrm{M}$ & $6 \mathrm{M}$ \\
\cline { 2 - 12 } & $\mathbf{- 0 , 0 0 6}$ & 0,003 & 0,001 & $\mathbf{- 0 , 0 0 8}$ & $-0,005$ & 0,009 & $-0,003$ & 0,006 & $-0,014$ & $-0,003$ & 0,004 & 0,017 \\
\hline
\end{tabular}

Note: Statistically significant results across all portfolios are highlighted in boldface Source: authors' calculations

For the reason that the results for individual portfolios are ambiguous, we cannot state whether short sale level is a bearish or bullish signal. Hence, we calculate average abnormal returns for the entire period and in chosen sub-periods (Table 6). For the entire sample, the difference in average abnormal holding period returns of portfolios representing ETFs with the largest versus smallest short positions is negative and significant for one-month return. For the sub-periods, the difference in average abnormal holding period returns between the smallest and largest ETFs short position is insignificant, with the exception of the sub period 2000 - 2006, when the negative one-month abnormal return was reached.

\section{Conclusions}

Short selling plays an important role in the ETF market. During the global financial crisis, it enhanced the market's quality and liquidity. This paper attempts to understand what makes investors short sell ETFs: specific ETF characteristics or the possibility of achieving abnormal returns. On the subject of the specific characteristics of exchange-traded funds as the rationale for short selling, we consider three hypotheses: overpricing, arbitrage and hedging and transaction costs. Using the monthly short interest ratio and characteristics of the ETFs traded in the US market, we find strong evidence to support all three short sale motivation hypotheses. The following factors influencing the level of ETFs short interest have been found statistically significant: trading volume, price stability, market capitalization, expense ratio, geographical focus, investment strategy and the availability of derivatives for the underlying index. However, the importance of certain determinants should be also assessed on daily data, once they are available in the open source, to capture the effects of everyday short sales trading strategies. Overall the evidence supports the overpricing and transaction costs hypotheses. If we compare our results with the studies on short selling with regular stocks (i.e. 
Diether et al. 2009), the rationale for short selling with both types of securities is at least similar.

We also show that the short selling of exchange-traded funds does not result on average in abnormal returns. Thus, short selling with ETFs unlike with stocks is not an additional investment technique, but merely a risk minimization technique to minimize losses in certain markets and regions.

\section{Acknowledgements}

The support of the Masaryk University internal grant MUNI/A/1025/2015 is gratefully acknowledged.

\section{References}

[1] ACKERT, L. F. and G. ATHANASSAKOS, 2005. The Relationship between short interest and stock returns in the Canadian Market. Journal of Banking and Finance, 29(7), 1729-1749. ISSN 0378-4266.

[2] AITKEN, M. F., M. S MCCORRY and P. SWAN, 1998. Short Sales are Instantaneously Bad News: Evidence from the Australian Stock Exchange. The Journal of Finance, 53(6), 2205-2223. ISSN 1540-6261.

[3] ANGEL, J. J., S. E. CHRISTOPHE and M. G. FERRI, 2003. A close look at short selling on the Nasdaq Market. The Financial Analysis Journal, 59(9), 66-74. ISSN 0015198X.

[4] BAYTAS, A. and N. CAKICI, 1999. Do markets overreact: International evidence. Journal of Banking and Finance, 23(7), 1121-1144. ISSN 0378-4266.

[5] BIGGS, B. M., 1966. The Short Interest - A False Proverb. Journal of Financial and Quantitative Analyst, 22(4), 111-116. ISSN 0015-198X.

[6] BOEHMER, E., CH. M. JONES and X. ZHANG, 2008. Which Shorts are Informed? The Journal of Finance, 63(2), 491-527. ISSN 1540-6261.

[7] BRENT, A., D. MORSE and K. E. STICE, 1990. Short interest: Explanations and tests. The Journal of Financial and Quantitative Analysis, 25(2), 273-289. ISSN 0022-1090.

[8] DECHOW, P. M., A. P. HUTTON and R. G. SLOAN, 2001. Short-sellers, fundamental analysis, and stock return. The Journal of Financial Economics, 61(1), 77-106. ISSN 0304-405X.

[9] DIETHER, K., K. LEE and I. WERNER, 2009. Short-sale strategies and return predictability. Review of Financial Studies, 22, 575-607. ISSN 0893-9454.

[10] DESAI, H., K. REMESH, S. THIAGARAJAN and R. B. BALACHANDRAN, 2002. An investigation of the informational role of short interest in the Nasdaq market. The Journal of Finance, 57(5), 2263-2287. ISSN 0378-4266.

[11] DIAMOND, D. W. and R. E. VERRECCHIA, 1987. Constraints on short-selling and asset price adjustment to private information. The Journal of Finance, 18(2), 277-312. ISSN 0378-4266.

[12] FIGLEWSKI, S., 1981. The Informational Effects of Restrictions on Short Sale: Some Empirical Evidence. Journal of Financial and Quantitative Analysis, 16(04), 463-476. ISSN 0022-1090. 
[13] JAGADEESH, N. and S. TITMAN, 1993. Returns to buying winners and selling losers: Implications for stock market efficiency. The Journal of Finance, 43, 65-91. ISSN 03784266.

[14] KERRIGAN, T. J., 1947. The Short Interest Ratio and Its Component Parts. Financial Analysts Journal, 30(6), 45-49. ISSN 0015-198X.

[15] KOT, H. W, 2007. What determines the Level of Short-Selling Activity? Financial Management [online]. [cit. 2013-02-16]. Available at: staffweb.hkbu.edu.hk/ hwkot/finance/papers/03_ShortInterest_FM.pdf

[16] MADURA, J. and T. NGO, 2008. Short interest in exchange-traded funds. Financial Market Portfolio Management, 22(4), 381-402. ISSN 1934-4554.

[17] MAYOR, T. H., 1968. Stock Trading Activity and The Price of Equities. The Journal of Financial and Quantitative Analysis, 3(3), 283-298. ISSN 0022-1090.

[18] MCDONALD, J. and D. BARON, 1966. Risk and return on short positions in common stocks. The Journal of Finance, 28(1), 97-107. ISSN 0378-4266.

[19] MCKENZIE, M. and Ó. T. HENRY, 2011. The determinants of short selling: evidence from the Hong Kong equity market. Accounting, 52, 183-216. ISSN 0810-5391.

[20] MILLER, E. M., 1977. Risk, Uncertainty, and Divergence of Opinion. Journal of Finance, 32(4), 1151-1168. ISSN 0378-4266.

[21] SENECA, J. J., 1976. Short interest: Bearish or bullish. Journal of Finance, 22(1), 67-70. ISSN 0378-4266.

[22] SMITH, R. D., 1968. Short Interest and Stock Market Prices. Financial Analysts Journal, 24(6), 151-154. ISSN 015-198X. 